Renata M. Sigva*

Kraków

\title{
Fethullaha Gülena koncepcja dialogu międzykulturowego
}

Fethullah Gülen, turecki myśliciel, duchowy wizjoner propagujący idee harmonijnego świata i pokoju międzyludzkiego, jest autorem nowego, interesującego głosu, dotyczącego dialogu, i to w aspekcie szeroko rozumianej międzykulturowości. Ciaggle mało znany, zwłaszcza w kręgu kultury europejskiej, autor ten od ponad 20 lat zaangażowany społecznie, aktywny jako pisarz i mówca, próbuje zmienić często stereotypowe i jego zdaniem nieprawdziwie oblicze islamu. Pisze o uniwersalnych dla różnych kultur i religii wartościach, takich jak: dobro, prawda czy odpowiedzialność, szuka odpowiedzi na pytania: jak żyć w zgodzie z innymi ludźmi?; jak doprowadzić do zbliżenia pomiędzy religiami?; jakie są wspólne wartości i dążenia ludzi różnych kultur? Odważnie propaguje idee pokojowe, bazując przede wszystkim na gruncie religijnym, wychodząc z założenia, że islam czy religia chrześcijańska stanowić mogą źródło podobnych wartości i stać się ważnym gruntem do budowania na ich zrębach dialogu międzykulturowego.

Celem niniejszego artykułu będzie próba zdefiniowania i dookreślenia koncepcji dialogu międzykulturowego, który to pozostaje w kręgu zainteresowań F. Gülena, i nie tylko jest to zauważalne w jego wielu tekstach, ale także w jego postępowaniu, tak że turecki myśliciel nazywany jest ,ad-

* Dr Renata Sigva jest adiunktem w Katedrze Teorii Wychowania i Opieki w Instytucie Pedagogiki Uniwersytetu Jagiellońskiego w Krakowie. Adres: Instytut Pedagogiki UJ, ul. Batorego 12, 31-135 Kraków; e-mail: renata.sigva@uj.edu.pl. 
wokatem dialogu". Autentyczność swoich teorii próbuje on podkreślić spotkaniami z przywódcami różnych religii, a najbardziej wyrazistym wskaźnikiem tego była jego wizyta w Watykanie w 1998 roku. Turecki myśliciel opisuje swoją wizję dialogu, odnosząc się do różnych wartości, natomiast w niniejszym artykule przedstawię tę triadę, która stanowi ramy dla dialogu międzykulturowego ${ }^{1}$. Spróbuję, na podstawie przede wszystkim źródłowych tekstów, dookreślić filary dialogu międzykulturowego, który to w koncepcji Gülena bazuje na uniwersalnych wartościach, takich jak: tolerancja, przebaczenie i miłość, rozpoczynając rzecz od ogólnych rozważań na temat dialogu i międzykulturowości. Przybliżę również portret człowieka międzykulturowego, który postawę dialogową buduje poprzez urzeczywistnianie powyższych wartości.

\section{Dialog i międzykulturowość}

Pojęcie dialogu we współczesnym rozumieniu pojawiło się stosunkowo niedawno, a sama filozofia dialogu, zwana także filozofią spotkania, zaistniała jako odrębny kierunek po I wojnie światowej. Wpływ na jej obecny kształt wywarli tacy myśliciele, jak: Ferdinand Ebner, Franz Rosenzweig, Martin Buber czy Józef Tischner. Szukając źródeł dialogu, musimy powrócić do Starożytności. Sokrates, prowadzący rozmowy ze swoimi uczniami, uczący ich odróżniać prawdę od fałszu - to osobowe i metaforyczne źródło greckiej tradycji filozoficznej; a obok niego Platon, dla którego dialog stanowił literacką formę wypowiedzi filozoficznej ${ }^{2}$. Kolejnym istotnym źródłem dialogu ${ }^{3}$ były inspiracje biblijne oraz niektóre nurty teologiczne rozwijane w ramach judaizmu i chrześcijaństwa. Kontekst religijny ujmował człowieka w dwóch istotowych momentach: jako jednostka pojawia się tylko w opozycji do innej osoby a wiedza ludzka polega na słuchaniu woli Bożej. Tak więc w takiej

${ }^{1}$ Celowo wskazuję na taki właśnie dialog, mając na uwadze fakt, iż Fethullah Gülen czyni przedmiotem swoich analiz także dialog międzyreligijny, bliski międzykulturowemu, nawet zawierający się w nim, ale mający jednak inną wykładnię i nie jest on tematem niniejszego artykułu.

2 Zob. Simon Blackburn, Platon. Państwo. Biografia, przeł. Anna Dzierzgowska (Warszawa: Muza SA, 2007).

${ }^{3}$ Można wyróżnić jeszcze więcej źródeł filozofii dialogu poza wskazanymi tutaj - jak np. nurt krytyczny wobec filozofii świadomości, neokantyzmu - por. m.in. Bogusław Milerski, „Pedagogika dialogu: filozoficzne inspiracje i perspektywy”, Paedagogia Christiana 1 (2008): 29-30. 
optyce spotkanie człowieka z Bogiem przyjmuje zawsze formę dialogu - jakiejś (bo przecież różnej) odpowiedzi na Boże wezwanie.

$\mathrm{Na}$ grunt pedagogiki problematykę dialogu wprowadził filozof, teo$\log$ i pedagog Martin Buber, i to w związku z jego osobą należy podkreślić szczególne zainteresowanie problematyką dialogu w początkach XX wieku, w tym filozofii tak zwanej wzajemnej relacji „Ja-Ty”. Pedagogika dialogu jest kierunkiem pedagogiki filozoficznej, który ujmuje relację wychowawczą w kontekście dialogicznej struktury bytu ludzkiego i proponuje określoną aksjologię pedagogiczna, która to odwołuje się do doświadczenia jednostki. Z perspektywy pedagogiki dialogu można formułować cele kształcenia i wynikające z nich kompetencje edukacyjne, których główną ideą jest uwrażliwienie na obecność człowieka ${ }^{4}$.

Przeobrażenia polityczno-społeczne ostatnich lat, jednocząca się Europa z ideą otwartych granic, wolnym handlem, wszechobecną mobilnością i migracją ludności odmieniły obraz świata i jednocześnie zrodziły nowe, często trudne wyzwania dla polityków, dysydentów, dla wychowawców. Współczesnych społeczeństw nie cechuje już homogeniczność i stałość, właściwie wszystkie kraje Europy stały się otwarte, a przez to i wielokulturowe. Słusznie wskazuje Wojciech Burszta, że „[...] wielokulturowy świat «wylewa się» niepowstrzymaną falą z wszelkich inicjatyw społeczno-kulturalnych, politycznych i edukacyjnych. Nie ma dnia, abyśmy nie byli powiadamiani, że coś ma wielokulturowość albo międzykulturowość"s. Międzykulturowość jest swoistym wyzwaniem, przed którym stoi dzisiejszy świat; wyzwaniem, które jest efektem dyfuzji kulturowych, migracji społecznych, stykania się różnych nacji i religii. Wydaje się więc, że ważnym zadaniem współczesnych czasów jest właśnie dialog międzykulturowy, zarówno w aspekcie dialogu między cywilizacjami, jak i religiami. Jest to wyzwanie istotne w obliczu współczesnego, skonfliktowanego świata, gdzie widzimy nie tylko ekonomiczno-polityczne problemy, ale także trudne do przezwyciężenia antagonizmy religijne. Niezwykle potrzebny jest więc dialog niwelujący różne stereotypy, uprzedzenia oparte nie tylko na trudnej historii, ale także na niewiedzy, braku chęci spotkania, przełamania występującego tabu.

W kulturze chrześcijańskiej najlepszym przykładem, a nawet symbolem próby pojednania zarówno międzykulturowego, jak i wyznaniowego

${ }^{4}$ Bogusław Milerski, „Aksjologia kształcenia w perspektywie pedagogiki dialogu”, Paedagogia Christiana 1 (2010): 150.

5 Wojciech Burszta, „Międzykulturowość — znamię czasów”, Kultura Wspótczesna 2 (2008): 16 
jest osoba Jana Pawła II. Dialog międzykulturowy i religijny był bardzo bliski Ojcu Świętemu, który poprzez cały swój pontyfikat starał się zbliżać do siebie narody i religie, a przede wszystkim człowieka do człowieka. Rola i znaczenie jego działalności w tym aspekcie są szeroko analizowane i znane w różnych kręgach kulturowych oraz religijnych. Warto także przybliżyć ideę dialogu międzykulturowego współczesnego tureckiego teologa - Fethullaha Gülena. Jego koncepcje mają ogromne znaczenie, dopóki muzułmańsko-chrześcijański dialog jest brany pod uwagę. F. Gülen jest współcześnie jednym z najbardziej wpływowych i istotnych głosów muzułmańskiej wspólnoty, nawołującym do dialogu jako istotnego kroku w kierunku ustanowienia pokoju na świecie ${ }^{6}$.

\section{Fethullah Gülen - szkic biograficzny}

Fethullah Gülen urodził się w 1941 roku w małej wiosce koło miasta Erzurum, położonego w północno-wschodniej Turcji. Jego rodzina miała silne korzenie religijne, ojciec był imamem, a matka była jego pierwszym nauczycielem Koranu. Poza zgłębianiem prawd religii islamu Gülen analizował krytycznie dzieła muzułmańskich uczonych, takich, jak: Said Nursi, Abu Hanifa czy Yunus Emre. W licznych pracach Gülena ${ }^{7}$ pojawia się nawiązanie zwłaszcza do idei kurdyjskiego myśliciela i duchownego Saida Nursiego. Jego poglądy stały się podstawą religijnego odrodzenia w Turcji drugiej połowy XX, lecz także początków XXI wieku. Nursi sprzeciwiał się filozofii pozytywistycznej i materialistycznej w wydaniu tureckim, cechującej się bezkrytyczną wiarą w postęp oraz naukę, a przy tym całkowitym negowaniem religii. Podkreślał on za to kompatybilność nauki i religii, wolności i wiary, nowoczesności i tradycji. Celem jego filozofii była ochrona zlaicyzowanej edukacji przed brakiem wiary w Boga, jak również ochrona edukacji religijnej przed fanatyzmem, poprzez ponowne zespolenie wartości wiary i nauki ${ }^{8}$. Właśnie takie tezy przyjmie F. Gülen jako podstawy swoich

${ }^{6}$ Por. Magdalena Lewicka, „Między teorią a praktyką - Gülenowski model dialogu międzywyznaniowego", w: Dialog chrześcijańsko-muzutmański. Klucz do wspólnej przyszłości, red. Magdalena Lewicka, Czesław Łapicz (Toruń: Wydawnictwo Naukowe UMK, 2012), 119.

7 Zob. m.in.: Fethullah Gülen, The Statue of Our Souls. Revival in Islamic Thought and Activism (New York: Tughra Books, Somerset, 2009); Fethullah Gülen, Toward a Global Civilization of Love and Tolerance (New York: Tughra Books, Somerset, 2004).

${ }^{8}$ Hakan Yavuz, Toward an Islamic Enlightenment: The Gülen Movement (Oxford/NY: Oxford University Press, 2013), 16. 
koncepcji. Myśli kurdyjskiego uczonego będą rzutowały na jego drogę poszukiwań badawczych.

Zdecydowaną większość swojego życia turecki uczony podróżował po Turcji prowadząc wykłady, dokonując odczytów nie tylko w meczetach, ale także w instytucjach świeckich, w tym zwłaszcza w ośrodkach akademickich. Dziś Gülen jest emerytowanym kaznodzieją, pisarzem i intelektualistą. Opublikował ponad 60 książek oraz wiele artykułów w różnych czasopismach. Jego prace zostały przetłumaczone na wiele języków. Jest przywódcą duchowym tak zwanego Ruchu Gülena stworzonego na podstawie jego poglądów. Ruch ten, zapoczątkowany w Turcji, dziś jest obecny w wielu krajach, mając charakter transnarodowy i jednocześnie nie stanowiąc organizacji politycznej. Członkowie tej organizacji prowadzą działania w różnych obszarach na całym świecie - w mediach, instytucjach biznesowych; propagują turecką kulturę, promują dialog, tworzą organizacje międzywyznaniowe oraz prowadzą sieć szkół. Po rozpadzie Związku Radzieckiego w 1991 roku Ruch Gülena zaczął zakładać szkoły także poza Turcją, najpierw w nowo powstałych republikach Azji Środkowej, a następnie także w innych krajach na wszystkich kontynentach ${ }^{9}$. Istotą tych szkół jest ich świecki charakter, różne szczeble funkcjonowania od przedszkola aż po szkoły wyższe i - co najważniejsze - mają one stanowić alternatywę dla szkół muzułmańskich. Jak wskazuje Yasien Mohammed, „W przeciwieństwie do placówek religijnych, wyznaniowych, szkoły Gülena są otwarte dla wszystkich bez względu na przekonania, są świeckie, ale gruntem ich funkcjonowania jest mocny rdzeń wartości moralnych i edukacja propagująca dialog, szacunek, tolerancję i odpowiedzialność"10.

Fethullah Gülen nazywany jest pedagogiem, edukatorem, nauczycielem, ale - co szczególnie znamienne - nie posiada on wykształcenia akademickiego z zakresu pedagogiki ani dziedzin jej pokrewnych. Nosi za to przydomek Hodża Efendi jako tradycyjne, honorowe określenie religijnego uczonego ${ }^{11}$.

9 Ramazan Arslan, „Ruch Gülena i jego wpływ na edukację i dialog międzykulturowy i międzyreligijny", Zeszyty Naukowe KUL 56 (2013), 222-223.

10 Yasien Mohammed, "The Education theory of Fethullah Gülen and its Practice in South Africa", w: Muslim World in Transition: Contributions of the Gülen Movement, red. Ihsan Yilmaz (Londyn: Leeds Metropolitan University Press, 2007), 23.

${ }^{11}$ Eugeniusz Sakowicz, Muzulmańska edukacja i wychowanie. Pedagogiczna wizja M. Fethullaha Gülena. (Białystok: Libra, 2014), 23. 


\section{Człowiek międzykulturowy według Fethullaha Gülena}

Punktem wyjścia w poniższej próbie rekonstrukcji poglądów Gülena na temat kształtu dialogu międzykulturowego warto uczynić krótkie prolegomena na temat międzykulturowości i człowieka międzykulturowego. W sensie filozoficznym międzykulturowość kontrybuuje człowieka jako osobę wolną, która staje się i wydaje się być nie tylko częścią, ale i wytworem zróżnicowanego kulturowo świata. W takiej konfiguracji ludzie wzajemnie uczą się i poznają, następuje swoiste wchodzenie w obszar aksjologicznej inności różnych grup w sposób jednak daleki od asymilacji ${ }^{12}$. A zatem międzykulturowość jest przenikaniem się i wymianą wartości różnych kultur, których rezultatami są i zgodna koegzystencja, i kompetencje kulturowe, w jakie wyposażony jest współczesny człowiek.

Międzykulturowość jako zjawisko nie jest z góry dane i dlatego, aby owo zjawisko mogło zajść, muszą być spełnione określone warunki, w tym odpowiednie relacje pomiędzy osobami w nim uczestniczącymi. Przemysław P. Grzybowski podkreśla, iż musi to być:

- adekwatna, trwała komunikacja miedzy zróżnicowanymi kulturowo partnerami, prowadząca do odkrycia różnicy w Innych/Obcych i sobie samym oraz nauki radzenia sobie z nią;

- wzmacnianie wewnętrznych dyspozycji partnerów do nawiązywania i podtrzymywania dialogu;

- poznanie efektu oddziaływania kultury i różnicy kulturowej na partnera $[\ldots]$

- zebranie wszelkich informacji o systemach kulturowych, ich zawartości i charakteryzujących je polach odniesienia, by być gotowym na ich przekroczenie i uczestnictwo w warunkowanych przez nie interakcjach w rozmaitych sytuacjach [...];

- integrowanie różnic Innego / Obcego w sąsiedztwie rozmaitych podobieństw $[\ldots]$ - podobieństwa często stanowią podstawę do stwierdzenia różnic $[\ldots]$;

${ }^{12}$ Leszek Korporowicz, „Od konfliktu do spotkania kultur, czyli tożsamość jako reguła autotransformacji”, w: Komunikacja międzykulturowa. Zbliżenia i impresje, red. Alina Kapciak, Leszek Korporowicz, Andrzej Tyszka (Warszawa: Wydawnictwo Instytut Kultury, 1995), 31. 
- zezwolenie Innemu/Obcemu na „poprowadzenie się”, by uzyskać wiedzę, w jakim stopniu jest możliwe wzajemne zbliżenie się ${ }^{13}$.

Nie sposób więc mówić o międzykulturowości bez aspektu zainteresowania, poznania, ale także i oceny innej kultury.

Konstytutywną cechą międzykulturowości jest charakterystyczne „pomiędzy", znajdujące się na pograniczu kultur, ale wyrastające na ich swoisty łącznik. Oczywiście to „pomiędzy” może zaistnieć tylko jako konsekwencja dialogu, dzięki któremu jednostka może wzmocnić swoje poczucie tożsamości, choć jednocześnie będzie to jej uczestnictwo we wspólnym tworzeniu, współdziałaniu.

Fethullah Gülen definiuje międzykulturowość zawsze w kategoriach spotkania, dialogu - w tym także międzywyznaniowego. Fundamentalnym tekstem, w którym Gülen podjął analizę istoty dialogu, była publikacja Toward a Global Civilization of Love and Tolerance ${ }^{14}$, w której to odnaleźć można także nawiązanie do jego listu przedstawionego Janowi Pawłowi II podczas jego znamiennej wizyty w Watykanie w 1998 roku $^{15}$. Problem człowieka uwikłanego w przemiany społeczne i cywilizacyjne, dychotomicznego w aspekcie nauki i religii, niespójnego w identyfikacji swojej tożsamości stanowi dla Gülena wyzwanie. Ale czy myśliciel ten próbuje rozwiązać ten dylemat, doopisać i przedstawić człowieka mając na uwadze jedynie przesłanki religijno-filozoficzne światopoglądu islamu? Otóż nie, bowiem tylko w perspektywie różnorodnej, wielokontekstowej, interdyscyplinarnej można - jak pisze Gülen - odczytać człowieka międzykulturowego. Tak więc Gülenowska optyka widzenia człowieka jako istoty w specyficznej sytuacji aksjologicznej ${ }^{16}$ pobrzmiewa $\mathrm{w}$ duchu różnych koncepcji filozoficznych, a zwłaszcza kantowskiej koncepcji człowieka. I chociaż Immanuel Kant, definiując człowieka jako istotę rozumną, samodoskonaląca, pragmatyczną, postępową, ale i o moralnym potencjale, wzoruje się wyłącznie na nauko-

${ }_{13}$ Przemysław Paweł Grzybowski, Edukacja europejska od wielokulturowości do międzykulturowości (Kraków: Oficyna Wydawnicza Impuls, 2008), 52-53.

${ }^{14}$ Gülen, Toward a Global Civilization, 27-28.

15 Por. Arhan Kardas, „Praktyczny wymiar dialogu w nauczaniu Fethullaha Gülena”, w: Dialog chrześcijańsko-muzułmański. Historia i wspótczesność, zagrożenia i wyzwania, red. Magdalena Lewicka, Czesław Łapicz (Torun: Wydawnictwo Naukowe UMK, 2011), 81-82.

16 Ta specyfika dotyczy wartości człowieka, które nadaje mu sam Bóg. Por. Koran, przekład i komentarz J. Bielawki (Warszawa: PIW, 1986). 
wych dogmatach, to jego koncepcja jest bliska Gülenowi ${ }^{17}$. W publikacji pod tytułem Pearls of Wisdom ${ }^{18}$ Gülen przekonuje, że człowiek doskonali się, żyjąc w świecie wartości ${ }^{19}$, dąży do spotkania z innym człowiekiem, innym ze względu na kulturę, język czy religię. To dążenie wynika zarówno z jego sfery poznawczej, racjonalnego definiowania siebie w świecie, jak i tęsknoty za drugim człowiekiem. Aksjologiczny wymiar egzystencji człowieka buduje swoiste pomiędzy - a jest nim międzykulturowość. I tutaj Gülen, tworząc triadę dialogu międzykulturowego ${ }^{20}$, nie tylko sięga do Koranu, ale także do Biblii czy do nauczania Jana Pawła II. Jest to koncepcja swoistego wychowania do dialogu międzykulturowego. Ma ona charakter profetyczny, jest inspirowana przeżyciem wiary w Boga i tworzy rys pedagogii Gülena, nazywanej przez niego samego pedagogiką odpowiedzialności lub pedagogiką dialogu. To interesujące zestawienie pojęć, które uczony identyfikuje jako wartości trwale ze sobą zespojone. Nie jest to koncepcja nowatorska, dialog zazwyczaj zakorzeniony był w takich wartościach, jak: prawda, wolność czy odpowiedzialność. Zauważamy więc tutaj ślad filozofii dialogu, której wpływom Gülen wyraźnie ulega, choć jej nie promuje. Podobnie jak Martin Buber, Gülen pisze: „człowiek dialogowy wychodzi ku przyszłości, kieruje się odpowiedzialnością za swoje myśli i czyny, za drugiego człowieka także"21. A sam dialog dla uczonego jest to ,spotkanie dwóch lub więcej osób [...] stworzenie więzi pomiędzy tymi ludźmi" ${ }^{22}$. Oczywiście nie odnajdziemy w tekstach Gülena stwierdzenia, iż odpowiedzialność najpełniej rozwija się w relacji „Ja-Ty”, a być może nawet tylko w niej. Uczony jest jednak daleki od uznania odpowiedzialności za swoisty moralno-praktyczny aspekt bycia w świecie z innym i dla innego człowieka. Tu prym wiedzie prawda objawiona, pedagogika odpowiedzialności i dialogu ma głębokie teleologiczne

${ }_{17}$ Por. Immanuel Kant, Antropologia w ujęciu pragmatycznym (Warszawa: IFIS PAN, 2010).

${ }^{18}$ Fethullah Gülen, Pearls of Wisdom (Fairvax Virginia: The Fountain, 2000), 55.

19 Widzimy tutaj zbieżność z myśleniem prezentowanym przez Józefa Tischnera, który to pisał: „Gdy mówimy, że nasz świat jest światem wartości, widzimy wokół siebie sprawy i rzeczy konkretne”. Józef Tischner, Myślenie wedtug wartości (Kraków: Społeczny Instytut Wydawniczy Znak, 1982), 483-484.

${ }^{20} \mathrm{~W}$ większości publikacji F. Gülen podkreśla istotną rolę przede wszystkim trzech wartości, w których zakorzeniony ma być dialog: tolerancji, przebaczenia i miłości. Por. m.in. Fethullah Gülen, Dialogue Is a Must, http://en.fGulen.com/content/view/1336/13/ [dostęp: 12.09.2015].

${ }^{21}$ Gülen, Toward a Global Civilisation, 23.

22 Podaję za: Lewicka, „Między teorią”, 121. 
przesłanie, zawierające się w odnowie duchowej i dokonującej się na tym gruncie zmianie społecznej. Jednak jest to dość oryginalne spojrzenie na islam i nie ma ono wiele wspólnego z fundamentalizmem religijnym. Dialog międzykulturowy budują tutaj trzy filary: tolerancja, przebaczenie i miłość. Te filary kreować mają człowieka nazywanego przez Gülena człowiekiem międzykulturowym. Przyjrzyjmy się zatem owym filarom.

\subsection{Tolerancja}

Bądź tak tolerancyjny, żeby twoje serce było rozpostarte niczym ocean ${ }^{23}$

W koncepcji Gülena tolerancja ma dotykać najpierw sfery religijnej, jej wskaźnikiem ma być otwartość na święte Księgi Żydów i chrześcijan, akceptacja wszystkich wyznań, w tym politeistycznych, a także ludzi niewierzących. Na tym gruncie ma kształtować się człowiek zainteresowany nowymi naukami, dziełami różnych uczonych, człowiek poszukujący, odkrywający, doskonalący się. Jest to więc próba zarysowania wizji człowieka typowej dla międzykulturowego paradygmatu o tożsamości pogranicznej. F. Gülen nie obawia się budowania takich tożsamości, podkreślając, że jest to domena współczesnych czasów, domena demokracji ${ }^{24}$.

Tolerancja według Gülena jest podstawą systemu moralnego człowieka, kontroluje ona nasz stosunek do innego człowieka, pozwala na akceptację jego inności i jest podstawą rozpoczęcia dialogu. Gülen pisze „,...] tolerancyjny człowiek jest sprawiedliwy w swoim oglądzie drugiego i potrafi zawsze otworzyć się na przeciwstawne idee i przyjąć je w takiej mierze, jaka będzie dla niego korzystna. Tolerancja nas oczyszcza i kształtuje pozytywne widzenie rzeczywistości”" ${ }^{25}$. Tolerancja jest procesem kształtowania człowieka aktywnego, intencjonalnego, definiującego w wielu kategoriach sytuację, którą dostrzega. Gülen wskazuje, że do tolerancji należy wychowywać, tak samo jak do innych wartości i tutaj ogromną rolę widzi turecki

${ }^{23}$ Fethullah Gülen, Criteria or Lights of the Way (EBook 2015), 71.

${ }^{24}$ Por. Gurkan Celik, The Gülen Movement: Building Social Cohesion Through Dialogue and Education (Delft: Eburon Publishers, 2011), 44.

${ }^{25}$ Fethullah Gülen, "Tolerance in the Life of the Individual and Society", http://en.fGulen. com/content/view/1800/33/ [dostęp: 18.09.2015 r.]. 
uczony w edukacji. Ignorancja, uprzedzenia, marginalizowanie wielu grup społecznych są skutkiem niewłaściwej edukacji ${ }^{26}$.

Fethullah Gülen w swoich pismach zawsze próbuje pokazać inny wymiar islamu, odpowiadając na uprzedzenia i swoiste naznaczenie tej religii zwłaszcza współcześnie. Uczony używa terminu Dżihad i nawet nawołuje do niego, ale w celu walki o tolerancję „Muzułmanie winni postępować zgodnie z duchem tolerancji i wyrozumiałości" ${ }^{27}$. Jest to więc zupełnie inna konstrukcja tego terminu, kojarzonego przede wszystkim z jego pejoratywnym znaczeniem. To próba wyjścia poza negatywne kategoryzowanie pojęć, to próba reinterpretacji w kierunku nowoczesnego widzenia islamu.

\subsection{Przebaczenie}

Analizując teksty Gülena na temat przebaczenia, można zauważyć, że autor ten widzi w tym akcie dwa wymiary: antropologiczny i religijny. Po pierwsze jest to cecha ściśle konstytuująca człowieka jako osobę - tylko ludzie mają zdolność do przebaczania. Człowiek jest zdolny do rozpoznania swojego cierpienia, krzywdy, zdefiniowania sytuacji, w której się znajduje. Ale może także - jak zauważa Gülen - coś więcej, i w tym momencie przydaje on przebaczeniu charakter aktu twórczego, który ma moc zmiany człowieka zniewolonego chęcią zemsty, uwikłanego w przeszłość, w kierunku tego, który staje się wolny ${ }^{28}$. Nowego stanu nabywa także ten, któremu przebaczamy, koryguje on swoje zachowanie (lub może to czynić) przez akt skierowany do niego, jako akt podania ręki, podniesienia i wezwania do swoistego odrodzenia. Przebaczenie zawsze skierowane jest od jakiegoś podmiotu do drugiej osoby, jako akt dynamiczny zmieniający obydwóch uczestników tej relacji. W koncepcji Gülena człowiek zdefiniowany jest jako skłonny do błądzenia. Uczony przywołuje zdanie Seneki, że błądzenie jest rzeczą ludzką i dodaje: tak samo ludzką jest rzeczą możliwość wybaczania. Przebaczanie jest celem wychowania człowieka. Uczony wskazuje, że „największym darem, jaki obecne pokolenie może dać swym dzieciom i wnukom, jest wpojenie w nich umiejętności wybaczania - nawet, gdy stawić musimy czoło najgorszemu zachowaniu i paraliżującym nas zdarzeniom" 29 .

\footnotetext{
${ }^{26}$ Tamże.

27 Podaję za: Lewicka, „Między teorią”, 126.

${ }^{28}$ Celik, The Gülen, 21.

${ }^{29}$ Podaję za: Sakowicz, Muzutmańska, 57.
} 
Spojrzenie Gülena na przebaczenie dokonuje się w optyce nie tylko muzułmańskiej religii, ale także wątków chrześcijańskiego spojrzenia na ten proces. Uczony ten uważa, że przebaczenie jest procesem oczyszczania pamięci, a samo natchnienie do tego, żeby przebaczać tak sobie samemu, jak i innym, ma swoje źródło w Bogu, który jako miłosierny uczy wszystkich przebaczenia. Odsyła więc Gülen swoich czytelników do wersetu Koranu „Kiedy przychodzi pomoc Boga i zwycięstwo, kiedy widzisz ludzi przystępujących tłumnie do religii Boga, głoś chwałę twego Pana i proś Go o przebaczenie! Zaprawdę, On jest ciagle przebaczający"30.

Gülen wychodzi poza ramy islamu, przywołuje słowa Jezusa Chrystusa zapisane w Ewangelii i wskazuje, że ukryty jest w nich największy sens przebaczenia. Wezwanie Jezusa skierowane do tłumu, który chciał ukamieniować grzesznicę i znamienne jego pytanie: „kto z was jest bez grzechu...” stanowi dla Gülena najgłębszą hermeneutyczną prawdę, zakorzenioną w przeszłości, a wyznaczającą ramy współczesnych czasów. Chrześcijański Prorok definiowany jest jako świadectwo prawdy i przebaczenia, jako przykład oraz temat do wielu rozpraw odczytujących sens przebaczenia ${ }^{31}$.

Gülen jest jednak ostrożny w swojej koncepcji przebaczania, jak również podkreśla, że człowiek nie posiada moralnego prawa przebaczać nieuczestniczącym w tym akcie osobom. Jednostki zakorzenione w złu, akceptujące i definiujące siebie w kategoriach im odpowiadających, po prostu nie zasługują na przebaczenie.

\subsection{Miłość}

Miłość jest powodem istnienia ${ }^{32}$.

Koncepcja miłości u Gülena jest związana z akceptacją drugiego człowieka, wynikająca po prostu z jego jestestwa, które zakłada poszanowanie jego godności i afirmację jego inności. I choć Gülen w swoich tekstach na temat miłości ${ }^{33}$ nie wymienia Karola Wojtyły, nietrudno nie zauważyć wielu podobieństw do stanowiska polskiego teologa. Gülen utożsamia miłość z działaniem, jest ona przez to dynamiczna i zawsze skierowana do jakie-

\footnotetext{
${ }^{30}$ Tamże, 58.

31 Gülen, Pearls of Wisdom, 52-54.

32 Podaję za: Lewicka, „Między teorią”, 127.

${ }^{33}$ Por. m.in. Fethullah Gülen, Towards the Last Paradise (Londyn: Truestar, 1995), 17.
} 
goś podmiotu. Wojtyła szukał źródeł miłości w człowieku, jako podmiocie świadomym własnego działania i wolnym w oparciu o jakiś porządek moralny ${ }^{34}$. Gülenowskie źródło miłości zawsze tkwi w Bogu. Człowiek jest odbiorcą tej wartości, może ją także odrzucać, ale sam jej nie kreuje. Turecki uczony używa zwrotu: powołani do miłości, tak bliskiego Wojtyle i dodaje: „Najbardziej widoczna jest miłość w praktycznym działaniu, dialogu międzyludzkim, międzywyznaniowym, międzykulturowym, staje się wówczas najlepszym lekarstwem na nienawiść, chaos i terror. Jesteśmy wezwani do miłości” ${ }^{35}$. Poprzez miłość człowiek staje się osobą dialogiczną, otwartą na drugiego człowieka, tęskniącą za nim, szukającą dróg do jego poznania. To stawanie się można odczytać $\mathrm{w}$ aspekcie rozwoju transcendentalnego, przekraczania własnych horyzontów, w których, zdaniem uczonego, człowiek aż za bardzo jest zakorzeniony, jest drogą do optymalnego rozwoju. Ale to nie jest oscylowanie wokół poszukiwania sensu swojego życia i próby jego nazwania poprzez zbliżenie się do drugiego człowieka. Gülen jest tutaj wierny zasadom Koranu, według którego człowiek jest już nazwany, jest już uposażony w momencie narodzin. Dar, który otrzymuje od Boga, jest ,sułtanem w jego sercu" 36 i to on kieruje zachowaniem człowieka oraz jego postawa wobec innego. Rodzi się pytanie, jak definiuje uczony swoje prawdy w stosunku do niewierzących. Gülen przyjmuje taki stan istnienia człowieka, pochyla się nad nim i parafrazuje własne stwierdzenia: „Jeżeli człowiek wierzący widzi się w oczach drugiego wierzącego, to możemy rzec, że człowiek jest po prostu lustrzanym odbiciem drugiego człowieka, także niewierzącego". Miłość jest bowiem dla Gülena tak zwaną wartością pierwszorzędną, podstawową, natomiast dążenie do nawrócenia, uznania Boga za najwyższe sacrum, jest wartością drugorzędną. Ponadto miłość, jako podstawa dialogu międzykulturowego, musi nawiązywać do tolerancji, a w tym układzie ich wzajemna komplementarność staje się wskaźnikiem prawdziwego otwarcia na drugą osobę, także niewierzącą.

\section{Uwagi końcowe}

Koncepcja budowania dialogu w wychowaniu międzykulturowym u Fethullaha Gülena nawiązuje i wyrasta z tradycji budowania dialogu między-

\footnotetext{
${ }^{34}$ Karol Wojtyła, Miłość i odpowiedzialność (Lublin: KUL, 2010).

35 Podaję za: Celik, The Gülen, 39.

${ }^{36}$ Gülen, Towards the Last, 13.
} 
religijnego, międzywyznaniowego. Turecki uczony zauważa, że występuje wyraźna dychotomia między religią a nauką. Religijność bywa widziana jako przeszkoda do postępu, a z kolei duchowni często odrzucają i nie przyjmują teorii naukowych, nowych odkryć służących rozwojowi człowieka. Gülen wskazuje na rozwiązanie tego antagonizmu w postaci nowej edukacji i odwołania się do świętych Ksiąg Koranu czy Biblii. Uczony ten postrzega prawa tam zapisane jako ,uniwersum, które zostało skodyfikowane i przelane na papier. W swoim autentycznym znaczeniu religia ani nie przeciwstawia się nauce i pracy naukowej, ani też ich nie ogranicza" ${ }^{37}$.

Nadrzędnym celem, nad którym należy się pochylić, jest znalezienie wspólnego mianownika dla rozwoju i wiedzy oraz różnorodności - w sensie pozytywnym - kulturowej i religijnej pomiędzy różnymi krajami, oddalenie konfliktów przez stworzenie podstawy dialogu i tolerancji oraz wsparcie dla globalnego braterstwa, ludzkości i pokoju.

Jako podstawowe zróżnicowanie kulturowe i religijne należy rozumieć protest przeciwko asymilacji, integracji tam, gdzie dialog oraz tolerancja wzajemnie na siebie oddziałują. Wzajemny dialog może jednak zapobiec konfliktom, otwierając ramiona na bogactwa, jak też zróżnicowanie kulturowe. Jedną z zasadniczych i przede wszystkim przyciagających uwagę cech wizji edukacji według Gülena jest wychowanie człowieka wzorcowego, zdolnego do myślenia w sposób pokojowy, ogólnoświatowy. Turecki uczony dokonuje swoistej reinterpretacji islamskiego rozumowania, celnie dopasowując je do współczesności, tak że czyni z owych rozważań nowy, potrzebny muzułmański dyskurs.

„Obecny, zniekształcony wizerunek islamu, który powstał na skutek niewłaściwego użycia tegoż obrazu tak przez muzułmanów, jak i nie-muzułmanów, przeraża zarówno jednych, jak i drugich" ${ }^{38}$. Gülenowska propozycja dialogu międzykulturowego ma być nie tylko kluczem do przezwyciężenia wielu obaw, stereotypów, ale i modelem do wspólnego bycia z innym człowiekiem.

37 Fethullah Gülen, „Edukacja od kołyski aż po grób”, w: Eseje, perspektywy, opinie, red. Fethullah Gülen (Somerset: The Light, 2007), 84.

38 Podaję za: Lewicka, „Między teorią”, 138. 


\section{Fethullah Gülen: his Concept of Intercultural Dialogue (Summary)}

Fethullah Gülen is a Turkish scholar, thinker, author, opinion leader and educational activist. The article is devoted to the issue of F. Gülen's intercultural dialogue. It presents Gülen's understanding of dialogue and his concept of dialogue in combination with tolerance, forgiveness and love. For Gülen, dialogue and these three universal values are the necessary elements for coexistence and ultimately, peace among the world's civilizations.

Key words: Gülen; intercultural dialogue; tolerance; forgiveness; love.

\section{Fethullaha Gülena koncepcja dialogu międzykulturowego (Streszczenie)}

Fethullah Gülen jest tureckim uczonym, myślicielem, pisarzem a także opiniotwórcą i działaczem oświatowym. Artykuł poświęcony jest przybliżeniu zagadnień związanych z dialogiem międzykulturowym w ujęciu F. Gülena. Zaprezentowano w nim rozumienie dialogu międzykulturowego według Gülena oraz koncepcję tego dialogu opartą na trzech filarach: tolerancji, przebaczeniu i miłości. Dialog i wymienione trzy uniwersalne wartości stanowią dla Gülena niezbędne składniki do zachowania pokoju na świecie.

Slowa kluczowe: Gülen; dialog międzykulturowy; tolerancja; przebaczenie; miłość.

\section{Bibliografia}

Arslan, Ramazan. „Ruch Gülena i jego wpływ na edukację i dialog międzykulturowy i międzyreligijny”. Zeszyty Naukowe KUL 56 (2013): 215-237.

Blackburn, Simon. Platon. Państwo. Biografia, przeł. Anna Dzierzgowska. Warszawa: Muza SA, 2007.

Burszta, Wojciech. „Międzykulturowość - znamię czasów”. Kultura Wspótczesna 2 (2008): 16-18.

Celik, Gurkan. The Gülen Movement: Building Social Cohesion Through Dialogue and Education. Delft: Eburon Publishers, 2011. 
Grzybowski, Przemysław Paweł. Edukacja europejska od wielokulturowości do międzykulturowości. Kraków: Oficyna Wydawnicza Impuls, 2008.

Gülen, Fethullah. Criteria or Lights of the Way. EBook, 2015.

Gülen, Fethullah. „Edukacja od kołyski aż po grób”. W: Eseje, perspektywy, opinie, red. Fethullah Gülen, 46-60. Somerset: The Light, 2007.

Gülen, Fethullah. Pearls of Wisdom. Fairvax Virginia: The Fountain, 2000.

Gülen, Fethullah. Toward a Global Civilization of Love and Tolerance. New York: Tughra Books, Somerset, 2004.

Gülen, Fethullah. Towards the Last Paradise. London: Truestar, 1995.

Gülen, Fethullah. The Statue of Our Souls. Revival in Islamic Thought and Activism. New York: Tughra Books, Somerset, 2009.

Kant, Immanuel. Antropologia w ujęciu pragmatycznym. Warszawa: IFIS PAN, 2010.

Kardas, Arhan. „Praktyczny wymiar dialogu w nauczaniu Fethullaha Gülena”. W: Dialog chrześcijańsko-muzulmański. Historia i wspótczesność, zagrożenia $i$ wyzwania, red. Magdalena Lewicka, Czesław Łapicz, 81-94. Toruń: Wydawnictwo Naukowe UMK, 2011.

Korporowicz, Leszek. „Od konfliktu do spotkania kultur, czyli tożsamość jako reguła autotransformacji”. W: Komunikacja międzykulturowa. Zbliżenia i impresje, red. Alina Kapciak, Leszek Korporowicz, Andrzej Tyszka, 31-40. Warszawa: Wydawnictwo Instytut Kultury, 1995.

Lewicka, Magdalena. „Między teorią a praktyką - Gülenowski model dialogu międzywyznaniowego". W: Dialog chrześcijańsko-muzułmański. Klucz do wspólnej przyszłości, red. Magdalena Lewicka, Czesław Łapicz, 117-142. Toruń: Wydawnictwo Naukowe UMK, 2012.

Milerski, Bogusław. „Aksjologia kształcenia w perspektywie pedagogiki dialogu”. Paedagogia Christiana 1 (2010): 149-159.

Milerski, Bogusław. „Pedagogika dialogu: filozoficzne inspiracje i perspektywy”. Paedagogia Christiana 1 (2008): 29-42.

Mohammed, Yasien. "The Education theory of Fethullah Gülen and its Practice in South Africa". W: Muslim World in Transition: Contributions of the Gülen Movement, red. Ihsan Yilmaz, 69-84. Londyn: Leeds Metropolitan University Press, 2007.

Sakowicz, Eugeniusz. Muzutmańska edukacja i wychowanie. Pedagogiczna wizja M. Fethullaha Gülena. Białystok: Libra, 2014.

Tischner, Józef. Myślenie według wartości. Kraków: Społeczny Instytut Wydawniczy Znak, 1982.

Yavuz, Hakan. Toward an Islamic Enlightenment: The Gülen Movement. Oxford/ NY: Oxford University Press, 2013.

Wojtyła, Karol. Miłość i odpowiedzialność. Lublin: KUL, 2010. 
